\title{
Lipomatosis simétrica benigna de la lengua en la enfermedad de Madelung
}

\section{Benign symmetric lipomatosis of the tongue in Madelung's disease}

\author{
A. López Ceres 1 , Y. Aguilar Lizarralde², A. Villalobos García 3 , E. Prieto Sánchez ${ }^{4}$, A. Valiente Álvarez
}

Resumen: La enfermedad de Madelung, o lipomatosis simétrica benigna es una enfermedad rara caracterizada por acúmulos grasos no encapsulados localizados de forma simétrica alrededor de cuello y hombros.

Esta enfermedad, afecta predominantemente a hombres en edades comprendidas entre los 30 y 60 años, con una relación hombre:mujer de 15:1. Existe una gran relación con el abuso del alcohol. Las personas no alcohólicas y las mujeres también pueden verse afectadas, aunque de forma más rara.

Presentamos el caso de una mujer diagnosticada de Enfermedad de Madelung refiriendo engrosamiento progresivo de la lengua. Presentaba dificultad para tragar, disartria y disnea con el decúbito.

Palabras clave: Enfermedad de Madelung; Lipomatosis simétrica benigna; Macroglosia.

Recibido: 03.11.2005

Aceptado: 23.03 .2006
Abstract: Madelung's disease, or benign symmetric lipomatosis, is an uncommon disease characterized by non-encapsulated accumulations of fat in a symmetric manner around the neck and shoulders.

This uncommon disease predominantly affects men between the ages of 30 and 60 and it has a 15:1 ratio. There is a strong correlation with alcohol abuse. Nonalcoholics and women can also be affected although this is rare.

We report the case of a woman diagnosed with Madelung's disease, who described a gradual swelling of the tongue. She had difficulty swallowing, dysarthria and dyspnea while sleeping.

Key words: Madelung's disease; Benign symmetric lipomatosis; Macroglossia.

\footnotetext{
1 Médico Residente de Cirugía Oral y Maxilofacial.

2 FEA de Cirugía Oral y Maxilofacial.

3 Médico Residente de Medicina Interna.

4 Médico Residente de Anatomía Patológica.

5 Jefe de Servicio de Cirugía Oral y Maxilofacial.

Complejo Hospitalario Carlos Haya, Málaga, España
} 


\section{Introducción}

La enfermedad de Madelung, o lipomatosis simétrica benigna es una enfermedad rara caracterizada por acúmulos grasos no encapsulados localizados de forma simétrica alrededor de cuello y hombros, y que rara vez afecta a caderas y miembros inferiores. Fue descrita por primera vez por Brodie en 1846 y Otto Madelung, en 1988 aportó una serie de 35 pacientes con lipomatosis cervical. A finales del siglo XIX, Launois y Bensaude (1898) documentaron más series y definieron el síndrome como la presencia de múltiples acúmulos grasos de forma simétrica que afectan cabeza, cuello y mitad superior del cuerpo. ${ }^{1}$

Esta enfermedad, afecta predominantemente a hombres en edades comprendidas entre los 30 y 60 años, con una relación hombre:mujer de 15:1. La mayor incidencia se encuentra en el área mediterránea, presentando en Italia una incidencia de 1/25000 hombres, ${ }^{2}$ y en casi todos los pacientes existe una gran relación con el abuso del alcohol. Las personas no alcohólicas y las mujeres también pueden verse afectadas, aunque de forma más rara. ${ }^{3}$

La enfermedad se define como la presencia de múltiples acúmulos grasos de forma simétrica, afectando generalmente al cuello, pared abdominal, espalda, axilas, torso y brazos.

La etiología es todavía desconocida. Generalmente se acompaña de una disfunción hepática debida al alcohol, ${ }^{4}$ y un un efecto lipogénico y antilipolítico. ${ }^{1}$ Asimismo, se ha observado una lipogénesis anormal inducida por las catecolaminas, ${ }^{5}$ y una posible asociación con lesiones hipofisarias e hipotalámicas tales como adenomas endocrinos, hipotiroidismo, acidosis tubular renal e hipertrigliceridemia. ${ }^{4}$

El diagnóstico debe establecerse fundamentalmente por los datos clínicos y por estudios de imagen como la TC, la Ultrasonografía o la RM. ${ }^{6}$

La lipomatosis de forma simétrica que afecte a la lengua como parte de la enfermedad de Madelung es muy rara, y ha sido previamente descrita en sólo tres casos. ${ }^{7-9}$

\section{Caso clínico}

Una paciente de 53 años de edad es derivada a nuestro servicio desde el departamento de Medicina Interna, diagnosticada de Enfermedad de Madelung, refiriendo engrosamiento progresivo de la lengua presentando cierta dificultad para tragar, disartria y disnea con el decúbito. Como antecedentes personales, la paciente presenta hipertensión y una hemicolectomía derecha por un carcinoma colorrectal hacía 5 años. No es obesa y niega abuso de alcohol.

A la inspección se observan múltiples masas lipomatosas alrededor del cuello, intervenida previamente (Fig. 1), axilas y cintura, que habían ido creciendo progresivamente durante los últimos cinco años. No presentaba adenopatías cervicales.

Presentaba un engrosamiento generalizado de la lengua que había producido una vestibulización de las arcadas dentarias. El rafe medio lingual tenía una apariencia normal, pero las caras laterales presentaban una superficie suave amarillenta (Fig. 2).

\section{Introduction}

Madelung's disease, or benign symmetric lipomatosis, is a rare disease characterized by an accumulation of nonencapsulated fat that is located in a symmetric manner around the head and shoulder's, rarely affecting the hips and lower limbs. It was first described by Brodie in 1846 and Otto Madelung in 1988 presented a series of 35 patients with cervical lipomatosis. Towards the end of the 19th Century, Launois and Bensaude (1898) documented further series and they defined the syndrome as the presence of multiple accumulations of fat in a symmetric manner affecting the head, neck and upper half of the body. ${ }^{1}$

This disease, which affects mainly men between the ages of 30 and 60, has a male/female ratio of 15:1. The greatest incidence is in the Mediterranean, and in Italy the incidence is of 1/25000 males. ${ }^{2}$ In nearly all patients there exists a strong link with alcohol abuse. Non-alcoholics and women can also be affected, although this is rare. ${ }^{3}$

The disease is defined as the presence of multiple accumulations of fat in a symmetrical manner, and it generally affects the neck, abdominal wall, back, armpits, torso and arms.

Its etiology is unknown. Generally it is accompanied by a hepatic dysfunction due to alcohol 4 and there is a lipogenic and anti-lipolytic effect. ' Catecholamine-induced abnormal lipogenesis has been observed5 together with a possible association with hypothalamo-hypophysary lesions such as thyroid adenomas, hypothyroidism, renal tubular acidosis and hypertriglicaridemia. ${ }^{4}$

The diagnosis should essentially be established with clinical data and imaging studies such as the CAT scan, ultrasonography or MRI. ${ }^{6}$

Symmetric lipomatosis affecting the tongue as part of Madelung's disease is very rare, and only three cases have previous been described. ${ }^{7-9}$

\section{Case report}

A 53-year-old patient was referred to our department by the department of Internal Medicine with a diagnosis of Madelung's disease. She reported a progressive thickening of the tongue and she had difficulties swallowing. She also had dysarthria and dyspnea in decubitus position. Her medical history included hypertension, a hemicolectomy of the right side as a result of a colo-rectal carcinoma five years previously. She was not obese and she denied alcohol abuse.

On inspection multiple lipomatous masses were observed around her neck that had been operated on (Fig. 1). Her armpits and waist had been growing progressively over the previous five years. There was no lymph node swelling in the neck.

There was a generalized swelling of the tongue that had produced a widening of the dental arches. The midline raphe 
Se realizó una tomografía axial computerizada, que demostró tejido adiposo mal definido invadiendo la musculatura lingual bilateral (Fig. 3).

La paciente fue intervenida bajo anestesia general, realizándose glosectomía bilateral de reducción, intentando respetar la punta de la lengua y la mayor parte de dorso posible para mantener la sensación gustativa. El tejido adiposo se entrelazaba con la musculatura lingual, y no se observaba cápsula (Fig. 4).

El postoperatorio inmediato transcurrió sin incidencias. Durante la intervención se colocó sonda nasogástrica para su alimentación, y la inflamación fue controlada con corticosterioides intravenosos. Fue dada de alta en el séptimo día postoperatorio. Los puntos fueron retirados al decimocuarto día (Fig. 5).

El estudio anatomopatológico revela una proliferación normal difusa de tejido adiposo con un aumento de elementos fibrosos y vasculares. No se identificó cápsula ni se observaron células atípicas.

A lo largo de la evolución postoperatoria, la disnea en decúbito y la disfagia han desaparecido, aunque persiste una mínima disartria objetivada por la propia paciente.

\section{Discusión}

La enfermedad de Madelung está caracterizada histológicamente por tejido adiposo múltiple, sin cápsula. La lipomatosis simétrica benigna que afecta al cuello es bien conocida, habiéndose publicado alrededor de 200 casos. ${ }^{10}$

A lo largo de los años, los depósitos de grasas alcanzan un gran tamaño, y llegan a ser estéticamente deformantes, y en casos avanzados, causan disnea y disfagia. ${ }^{11}$ Después de una cirugía o de un traumatismo, el crecimiento puede acelerarse.

La laringe puede verse afectada no sólo por compresión directa grasa, sino por infiltración del nervio laríngeo recurrente. ${ }^{12}$

El examen histológico muestra que las células lipomatosas en las zonas anormales son totalmente indistinguibles de aquellas que se encuentran en el tejido adiposo normal, aunque estudios ultra-

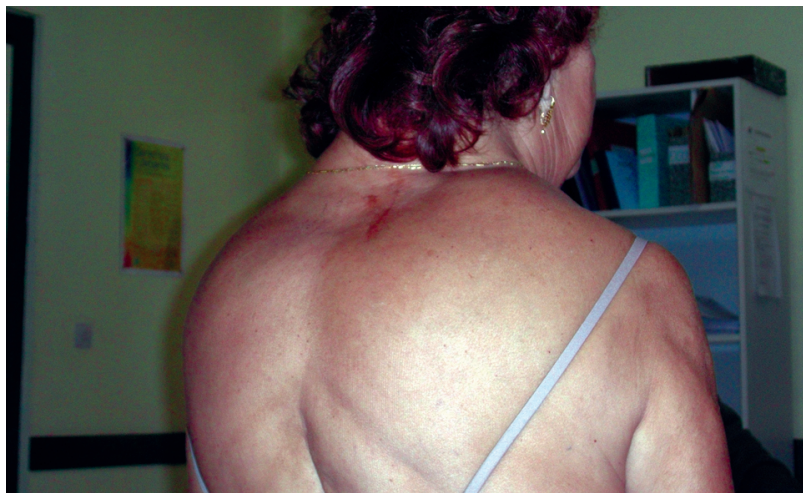

Figura 1. Paciente con Enfermedad de Madelung.

Figure 1. Patient with Madelung's disease.

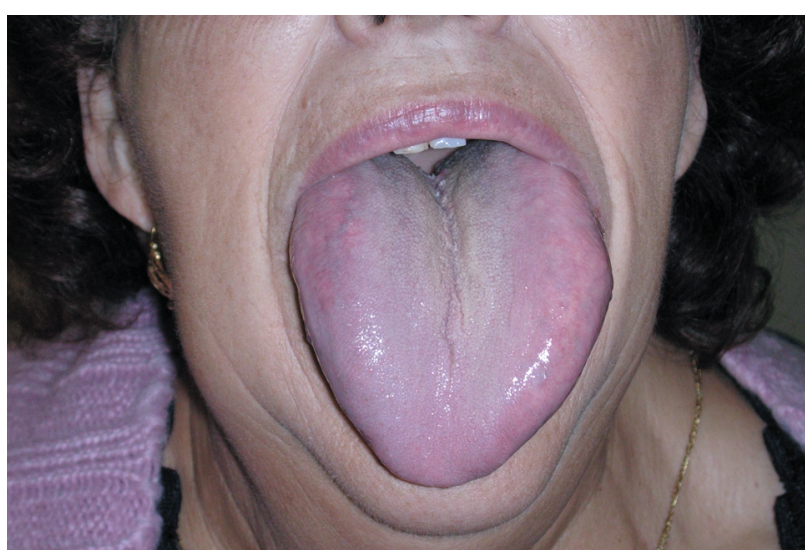

Figura 2. Macroglosia.

Figure 2. Macroglossia.

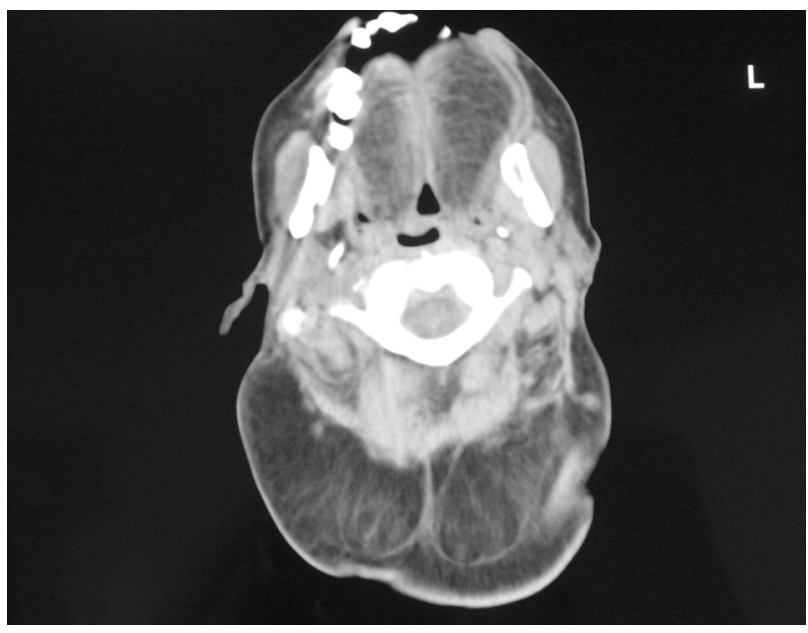

Figura 3.TC.

Figure 3. CT scan. of the tongue had a normal appearance but the lateral areas had a surface that was smooth and yellow (Fig. 2). A computed axial tomography was carried out that showed ill-defined adipose tissue invading the lingual muscles on both sides (Fig. 3).

The patient was operated on under general anesthesia. A bilateral glossectomy was performed to reduce the tongue, and an effort was made to try and respect the tip and most of the back in order to maintain a perception of taste. The adipose tissue was intermixed with the muscles of the tongue, and capsules were not observed (Fig. 4).

The immediate postoperative period was incident-free. During the intervention a nasogastric feeding tube was positioned, and the inflammation was controlled with intravenous corticosteroids. She was discharged on day 7 of the postoperative period. The stitches were removed on day 14 (Fig. 5).

The anatomopathological study revealed a diffuse proliferation of adipose tissue that was normal, and an increase in fibrous and vascular elements. Capsules were not identified nor were atypical cells observed.

During the postoperative period, the dyspnea in decubitus position and the dysphagia disappeared, although there was minimal dysarthria observed by the patient herself.

\section{Discussion}

Madelung's disease is characterized histologically as multiple deposits of non-encapsulated adipose tissue. Benign symmetric lipomatosis affecting the neck is well known, and 
estructurales han demostrado que los adipositos de la enfermedad de Madelung son más pequeños y multivacuolados, sugiriendo por ello un posible origen en la grasa parda. ${ }^{2}$ Asimismo, las masas tienden a estar más vascularizadas que el tejido adiposo normal, produciendo por ello un mayor sangrado que debe preveerse en el momento de la cirugía, tanto en el acto quirúrgico, como para la reposición volémica postoperatoria.

Tan sólo existe un caso publicado de una transformación maligna hacia liposarcoma mixoide. ${ }^{13}$ La asociación de la Enfermedad de Madelung con otras neoplasias parece deberse a la combinación del alcoholismo crónico y el abuso de nicotina que suele estar presente en estos pacientes, que presentan por tanto una mayor susceptibilidad a ciertas neoplasias. ${ }^{14}$

En el momento del diagnóstico es importante considerar otras entidades tumorales. Asimismo, la macroglosia puede estar presente en una gran variedad de condiciones, como síndromes congénitos, enfermedades metabólicas, endocrinas, o pueden aparecer en otras como amiloidosis, hialinois o tumores linguales. ${ }^{15}$

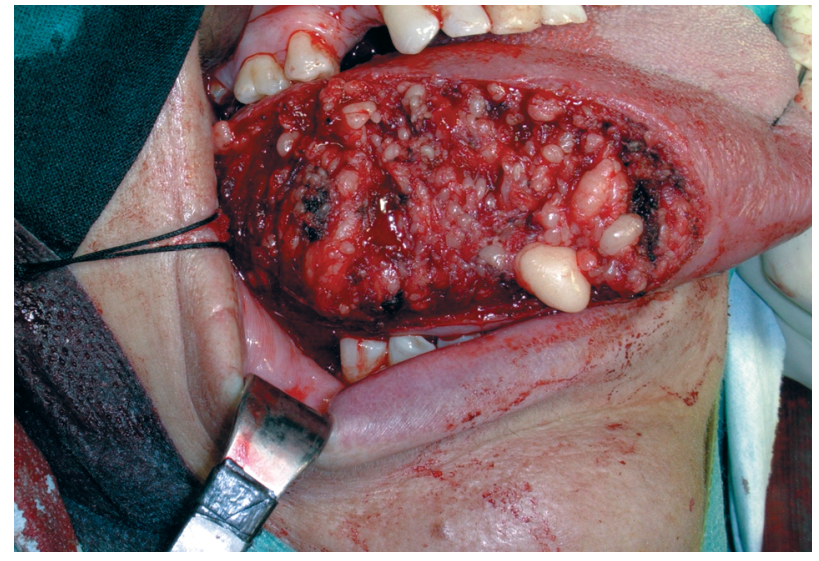

Figura 4. Imagen intraoperatoria. Figure 4. Intraoperative view.

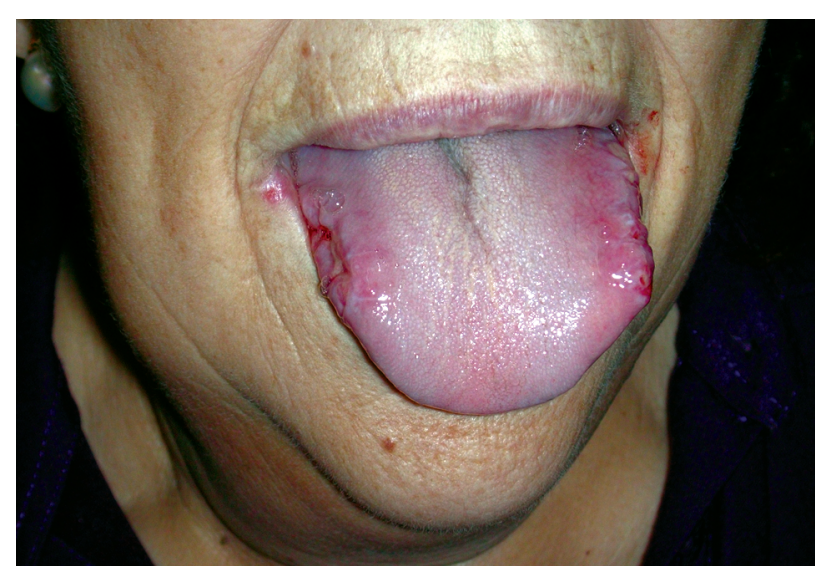

Figura 5. Decimocuarto día postoperatorio. Figure 5. Postoperative day 14.

around 200 cases have been published. ${ }^{10}$

Over the years large amounts of fat deposits are accumulated, and they become esthetically deforming, and in advanced cases this may cause dyspnea and dysphagia. ${ }^{11}$ After surgery or trauma there may be an increase in growth.

The larynx may be affected not only as a result of direct compression by the fat, but also because of the recurrent infiltration of the laryngeal nerve. ${ }^{12}$

The histological examination shows lipomatous cells in abnormal areas that are totally indistinguishable from those that are in normal adipose tissue, although ultrastructural studies have demonstrated that adipose cells in Madelung's disease are smaller and multivacuolated, which suggests that it has a possible brown fat origin. ${ }^{2}$ Likewise, the masses tend to be more vascularized than normal adipose tissue and, as a result, greater comienza con un primer período de crecimiento rápido, seguido de una progresión lenta. No existe ningún caso publicado de regresión espontánea de los lipomas, a pesar de abandonar el hábito alcohólico. La causa de la disnea, disfagia y disartria no deben ser atribuidas a la compresión grasa hasta que no se hayan descartado otras patologías de la vía aérea.

El tratamiento está limitado a la resección quirúrgica del tejido adiposo, bien directamente o por liposucción. La cirugía está indicada en los pacientes con severa deformidad, cuando causan alteraciones psicológicas, y si hay compresión de la vía aerodigestiva que causen disnea o disfagia. ${ }^{11}$ La restricción dietética no causa ninguna mejoría. Dado que la excisión completa del tejido adiposo no se puede llevar a cabo, la recidiva es lo más común después de la intervención, por ello los pacientes deben ser advertidos. ${ }^{6}$ Se han utilizado los $ß 2$ agonistas (salbutamol)1,5,10 y la inyección intralesional de enoxaparina, ${ }^{5}$ como tratamiento médico, sin ninguna eficacia.

Cuando hay afectación lingual, el tejido adiposo penetra de forma profunda, por tanto, la resección completa de la lesión es casi imposible, ya que resultaría en la resección subtotal de la lengua. Al planear la glosectomía, el volumen de resección debe ser cuidadosamente planificado, teniendo en cuenta el tamaño y forma de la lengua en el postoperatorio.

bleeding should be envisaged during the surgical act as well as during postoperative volemic replacement.

There is only one case published on malignant transformation to myxoid liposarcoma. ${ }^{13}$ The association of Madelung's disease with other neoplasms appears to be due to the combination of chronic alcoholism and nicotine abuse that appears to be present in these patients, and who are susceptible to certain neoplasms. ${ }^{14}$

On diagnosis it is important to keep in mind other tumoral entities. Macroglossia may be present in a large variety of conditions, such as congenital syndromes, metabolic and endocrine diseases, or it may appear in others such as amyloidosis, hyalinois or lingual tumours. ${ }^{15}$

The clinical course of the disease starts with an initial period of rapid growth, followed by slow progression. There is no case published regarding the spontaneous regression of lipomas, in spite of abandoning alcohol. The cause of dyspnea, dysphagia and dysarthria should not be attributed to fat compression until other pathologies of the airways have been eliminated.

Treatment is limited to the surgical resection of the adipose tissue, either directly or through liposuction. Surgery is 


\section{Conclusiones}

Hemos presentado el caso de una paciente diagnosticada de Enfermedad de Madelung que presenta un cuadro de macroglosia, ya descrito en otros tres trabajos, lo que nos debe hacer pensar que la afectación lingual pueda ser otra característica de la enfermedad de Madelung, que se presenta en raras ocasiones, pero existe.

Su tratamiento es quirúrgico, cuando presenta complicaciones obstructivas dado el tamaño que puede alcanzar la lengua, siempre teniendo en cuenta que la norma es la recidiva.

\section{Bibliografía}

1. Parmar SC, Blackburn C. Madelung's disease: an uncommon disorder of unknown aetiology? Br J Oral Maxillofac Surg 1996;34:467-70.

2. Enzi G. Multiple symmetrical lipomatosis: an updated clinical report. Medicine 1984;63:56-64.

3. García JA, Dean A, Alamillos F, Ruiz JJ, Peñalba M, Zafra F, Barrios G. Enfermedad de Madelung. Presentación de un nuevo caso y revisión de la literatura. Rev Esp Cir Oral Maxilofac 2003;25:165-9.

4. Ogawa A, Nakamura H, Takahashi H. Benign Symmetric Lipomatosis of the Tongue: report of a case. J Oral Maxillofac Surg 1988;46:502-4.

5. González-García R, Rodríguez-Campo FJ, Sastre-Pérez J, Muñoz-Guerra MF. Benign Symmetric Lipomatosis (Madelung's disease): Case reports and current management. Aesthetic Plast Surg 2004;28:108-12.

6. Ujpal M, Nemeth ZS, Reichwein A, Szabo GY. Longterm results following surgical treatment of benign symmetrical lipomatosis (BSL). Int J Oral Maxillofac Surg 2001;30:479-83.

7. Duvar M, Pollet L, Herrenschmidt JC. Lipoma de la langue au cours d'une lipomatose symmétrique. Bull Mém Soc Med Hosp 1957;53:174-8.

8. Ghislain PD, Garzitto A, Legout L, Alcaraz I, Creusy C, Mediano P. Lipomatose bénigne symmétrique de la langue et lipomatose de Launoios`Bensaude. Ann Dermatol Venereol 1999;126:147-9.

9. Vargas-Díez E, Daudén E, Jones-Caballero M, García-Díez A. Madelung’s disease involving the tongue. I Am Acad Dermatol 2000;42:511-3.

10. Adamo C, Vescio G, Battaglia M, Galleli G, Musella S. Madelung's disease: case report and discusion of treatment options. Ann Plast Surg 2001;46:43-5.

11. Palacín JM, Grande N, Rabell J, Sarobé N, Uribe I. Tratamiento quirúrgico de la lipomatosis cervical. Rev Esp Cir Oral Maxilofac 1998;20:257-63.

12. Argenta LC, McClatchey KD, Ferrel WJ, Newman MH. Benign symmetrical lipomatosis. Head Neck Surg 1981;3:240-3.

13. Tizian C, Berger A, Bukoupil KF. Malignant degeneration in Madelung's disease (benign lipomatosis of the neck): case report. Br J Plast Surg 1983;36:187-9.

14. Chan ESY, Ahuja AT, King AD, Lau WY. Head and neck cancers associated with Madelung's disease. Ann Surg Oncol 1999;6:395-7.

15. Lee HW, Kim TH, Cho W, Ryu BY, Kim HK, Choi CS. Multiple symmetric lipomatosis: Korean experience. Dermatol Surg 2003;29:235-40. indicated for those patients with severe deformity, when there are psychological disturbances, and if there is compression of the aerodigestive tract causing dyspnea or dysphagia. ${ }^{11}$ Dietary restrictions do not cause any improvement. Given that total excision of the adipose tissue cannot be carried out, relapse is common after the intervention, and patients should be warned of this. ${ }^{6}$ B2 agonists (salbutamol) $1,5,10$ and intralesional injections of enoxaparin5 have been used as medical treatment but to no avail.

When the tongue is affected, adipose tissue penetrates deeply and, as a result, the complete resection of the lesion is nearly impossible as this would result in the subtotal resection of the tongue. On planning the glossectomy, the volume to be resected should be carefully planned, bearing in mind the postoperative size and shape that the tongue is to have.

\section{Conclusions}

We have presented the case of a patient diagnosed with Madelung's disease that had symptoms of macroglossia as described in another three articles. This should lead one to think that the involvement of the tongue is another characteristic of Madelung's disease, which is very rare but that does exist.

Treatment is surgical when there are obstructive complications given the size that the tongue can reach, but it should always be kept in mind that relapse is the norm. 